\title{
Analysis and Significance of Weather and Climatic Trend on Outdoor Sculptures in Southwest, Nigeria
}

\author{
Aremu Oluwasegun ${ }^{1 *}$, Ijisakin Yemi ${ }^{2}$, Bello Emanuel ${ }^{1}$ and PSO Aremu \\ ${ }^{1}$ Nigerian Meteorological Agency, Gwaska, Nigeria \\ ${ }^{2}$ Fine and Applied Arts, Obafemi Awolwo University, Ilelfe, Nigeria
}

\begin{abstract}
Celebration and commemoration are what we deem fit to showcase historical values of heroes and important people in the society. These are done through various means such as - street naming, excellent awards, chieftaincy titles, and icons on generally acceptable objects of use like currency, dedicating images and creating artworks. Outdoor sculpture, as an appendage of public art, fits into this scenario. It can be defined as a three-dimensional (3-D) or relief work of art or design created by sculptors, and specifically cited in a restricted or unrestricted open space, it can be small or big, life or above life size, or colossal in size. To critically access the role and effect of weather on outdoor Sculptures in Southwestern Nigeria, we have to define weather or simply imply that this project is the definition of weather on outdoor sculptural pieces which could be simply defined as " The state of atmosphere on a particular space and time as regards various climatic variables such as Rainfall, Temperature and Humidity etc. as they affect outdoor sculptures in the Southwestern part of Nigeria, depending on the type of material used for their execution. Sculptures can be carved, modeled, cast, constructed or assembled in whatever form as they attract attention where they are placed. The effect of weather on these sculptures communicates community values, heighten awareness, question assumptions, and transform a landscape; they can have the power, to transform the images in the area of existence over time. To corroborate this, Ref. [1] posits that 'we can celebrate our loved ones and heroes, with these images we can as well use these sculptural pieces to celebrate our ideals. She goes further to affirm that after some time, less interest is shown by people toward the care of these sculptures. As good as various outdoor sculptures are in the environment they exist, they face unprecedented threats from the effects of weather, most especially when a few people recognize further responsibility towards their care. Artists as well as Meteorologists understand the abrupt humidity and temperature change or other climatic variables on artworks, over time which affects the outdoor sculptures. Expansion, corrosion and contraction weaken fundamental materials of outdoor sculptures. The uneven "breathing" causes a break in the adhesion between different types of materials used in the formation. The result of these negative tendencies can cause breakages and peeling of materials. Relative humidity, Temperature and Rainfall are considerably most important climatic variable affecting outdoor sculpture in this region. This scenario is not unconnected with DeChillo [2] (ibid) affirmation that "metals tarnish, bronze corrodes, and marble and even resin crack". This paper therefore identifies and analyzes the various harsh effects of weather on outdoor sculptures in Southwest Nigeria, it also catalogues suggestive ways of ameliorating the effects.
\end{abstract}

Keywords: Sculptures; Climatic variable; Environment; Rainfall

\section{Introduction}

Temperature (Max and Min) and Relative humidity trend analysis on different spatial and temporal scale has been a great concern during the past century because of the attention given to global climate change by the scientific community [3]. The aim of this study is to analyze Rainfall, Temperature (Max and Min) and Relative humidity time series over a period of time interval located in the study area. Present-day outdoor sculptures continue to challenge traditional concepts of 3-D art through their new spatial concepts and use of everyday materials assembled or created in numerous installation-types and fixed forms of sculpture. Equally, there has been some remarkable development in the production and use of outdoor sculptures in Southwest Nigeria. Among the outstanding examples used are-the ancient monolith staff of Oranmiyan situated in Ile-Ife and of which the history of the artist that produced the work remains a mystery. The bronze statue of Sango, displayed in front of Electric Corporation of Nigeria (ECN), Marina, Lagos and that of the Queen of England, Elizabeth II, placed in front of the House of Representatives in Lagos, were produced by the first indigenous western-trained artist - Ben Enwonwu in 1956 and 1960 respectively. All outdoor sculptures are used to pass across information. Often, they tell something about the place they are located, or the people who are living near them now or those who have lived there in the past, weather parameters affect outdoor sculptures which invariably indicate time of existence of the sculptures. The large variability in time and space requires that, for accurate unbiased results, long-term climate analyses can be based on homogeneous data. A homogeneous climate data series could be defined as one where variations are caused only by variations in weather and climate [4]. A careful study of outdoor sculptures in Southwest Nigeria reveals a range of different types of sculptures, discovers the history behind these sculptures, and what they mean to the people. The importance of outdoor sculpture cannot be overemphasized, in the face of the submission of Ref. [5] that sees public sculptures as surprising artistic interventions in the landscape which supply psychological, social, and political benefits to people. Outdoor sculptures can be subjected to Climatic phenomena, such as rainfall onset failure, droughts, floods, humidity, temperature and related

*Corresponding author: Aremu Oluwasegun, Nigerian Meteorological Agency, Ring Road 4, Gwaska, Nigeria, Tel: 08036231223; E-mail: segunaremu007@hotmail.com

Received August 02, 2016; Accepted August 26, 2016; Published September 01, 2016

Citation: Oluwasegun A, Yemi I, Emanuel B, Aremu PSO (2016) Analysis and Significance of Weather and Climatic Trend on Outdoor Sculptures in Southwest Nigeria. J Environ Anal Toxicol 6: 400. doi: 10.4172/2161-0525.1000400

Copyright: (c) 2016 Oluwasegun A, et al. This is an open-access article distributed under the terms of the Creative Commons Attribution License, which permits unrestricted use, distribution, and reproduction in any medium, provided the original author and source are credited. 
Citation: Oluwasegun A, Yemi I, Emanuel B, Aremu PSO (2016) Analysis and Significance of Weather and Climatic Trend on Outdoor Sculptures in Southwest, Nigeria. J Environ Anal Toxicol 6: 400. doi: 10.4172/2161-0525.1000400

Page 2 of 15

features which may occur at regular or irregular time intervals and may be of short or long duration or of small or large scale. Their persistence over a specified period of time can be defined in terms of a trend, while their regular reoccurrences can be defined in terms of 'periodicities'. Periodicities are predictable cyclic occurrences of weather phenomena over time. Ref. [6] further affirms that such interventions enable their audiences to access moments of surprising inspiration, self-reflection, and revitalization. These spontaneous moments may offer access to the experience of distance from the rational "self," allowing the irrational and purely emotive that resides within all humans to assert itself. This sensual instinct is too frequently, pushed aside by the average person particularly in the public realm for the sake of responsibilities deemed more worthy.

The aesthetic appeal of sculptures used as public monuments found in various restricted and unrestricted public places in Southwestern Nigeria's towns and cities cannot be over-emphasized; they are usually executed to tell stories of various ancient towns and their heroes and heroines, this outdoor sculptures have been really degraded by the potent power of weather which sometimes indicate conflicting report of existence through time.

Necessarily outdoor sculptures enhance beauty of the built environment, therefore in order to ensure the sustenance of outdoor sculptures in the environment where they exist, there is the need to understand the effects of weather variability on the works so as to be able to make forecast and trend analysis of climatic variable in order to allow us take precautions and equally proffer ways of maintaining them for posterity. To understand the impact of climate change or extreme climatic events, a good historical base is needed. Trend analysis will be performed on extreme precipitation events of various durations for stations within and near the case study area.

The trend results or predictions will provide a general idea of any changes noticeable within the historical (Climatic) data and point out certain concerns for the area regarding extreme climatic events. One intent of the investigation to be carried out in this study is to establish whether the current trend as determined by the trend analysis will match the projections of future conditions for the outdoor sculptures.

There are quite a good number of outdoor sculptures world over. Most of these have turned out to be tourist centres that fetch the owner countries lots of revenue. If these countries of note have hitherto neglected their outdoor sculptures, the sculptures would not have become world-renowned icons talk less of becoming a 'must visit' for the tourists.

Hence, this paper examines the impact of weather in the longterm how it affects outdoor sculptures located in unrestricted public places such as roundabouts, road junctions, roadsides, markets, town squares, and parks in Southwestern Nigeria, with a view to suggesting ways of making climate prediction and trend analysis for appropriate maintenance processes.

\section{Remediation of Weather Ravaged Outdoor Sculptures}

The effects on both traditional and modern materials exposed to weather condition are unquantifiable. Acid rain is said to ruin buildings and statues by stripping away the stone that was used to construct buildings and statues that were meant to be exposed and used as outdoor decorations. The natural forces and agents of weather may have a degrading effect on the appearance and structural soundness of marble. Bronze sculpture can be disfigured by the corrosive work of acid rainwater run-off. Concrete figures are susceptible to cracks and surface wear through internally generated heat that causes expansion and contraction and run-off water respectively. The only saving grace is regular, correct maintenance that will add significant years to the lifespan of outdoor sculptures. Conversely, a decade without maintenance is often, all that is needed to return outdoor sculptures to poor situation.

Aside the meteorological conditions, affirms by Ref. [7], air pollution is believed to adversely affect outdoor artworks as the traditional outdoor pollutants including sulfur dioxide, nitrogen oxides, and ozone affect the various composite materials. The specific level and type of air pollution degradation is dependent on the material and composition of the artwork as well as the length of exposure. Corrosion issues arise on outdoor sculptures from time to time, this requires investigation and remedial actions taken as advised by conservation specialists who are professionally trained to carry out conservation and restoration processes on outdoor or public art using established scientifically based remediation methodologies. Mitigating the ravages of weather on outdoor sculptures requires the timely preventive conservation that involves actions taken to delay deterioration of cultural heritage. For outdoor artworks, this usually involves the application of a protective coating and regular maintenance. It is pertinent to add that, durability, adhesion to the surface, ease of maintenance, and surface appearance on the work determines the particular protective coating to be used.

These works may be made of wood, stone, ceramic material, plastic, bronze, copper, or any other number of materials which may or may not be painted. When applied to cultural heritage, this activity is generally undertaken by a conservator-restorer. Before any conservation treatment is carried out on depreciated outdoor sculpture, a thorough condition assessment with written and photographic documentation is necessary. The initial assessment may include a research into the technique adopted by the artist to evolve the work initially, and better still, a discussion with the living artist, to review the conservation history of the object, as well as non-destructive analysis of the procedure. Maintenance of outdoor sculpture is the key to slowing the inevitable ravages of weather. However, this requires timely intervention, and the involvement of a trained, and experienced conservator. The treatment of outdoor artworks is multifaceted and dependent on the material type, condition, and structural integrity.

\section{Bronze sculptures}

For many bronze sculptures and other metal sculptures, treatment includes a reduction in buildup from previous protective coatings, removal of corrosion and incrustation or cleaning. This may be done by hand, water blasting, air abrasion, or other methods. Then, a wax or wax composite is applied to the sculpture in sweeping motions. The wax is then buffed with a cotton cloth.

\section{Stone sculptures}

It is noted that a long time deposits of soil from airborne circulation on sculptures are enough to support the growth of fungal cells especially on porous stone. The moment this occurs, the roots of such growth is said to penetrate the body of the sculpture, and deterioration cycle sets in by staining the sculpture with products of soil digestion and if left uncared for, destruction of the work is inevitable. If we are appreciative of our artworks and memorials, it is better to take immediate precautionary measures before significant damage is done.

\section{Painted sculptures}

According to Ref. [8], painted sculptures are actually a multilayered composition that can contain primers, paints, and protective 
Citation: Oluwasegun A, Yemi I, Emanuel B, Aremu PSO (2016) Analysis and Significance of Weather and Climatic Trend on Outdoor Sculptures in Southwest, Nigeria. J Environ Anal Toxicol 6: 400. doi: 10.4172/2161-0525.1000400

coatings as well as the structural substrate. Problems that may occur with painted sculptures include degradation or alteration of color, cracking and flaking of paint, and failure of the primer layer which exposes the underlying primary support to the elements, as observed in the statue of Oduduwa. Treatments of painted sculptures may include reduction of previous coatings and repairs, cleaning and consolidation.

Plastic sculptures: Plastic elements are prevalent in contemporary sculptures. Outdoor sculptures may be made entire or in part of polyester, epoxy, phenol, or acrylic materials Ceramic sculptures: Ceramic sculptures are much less common than bronze sculptures, and require a different conservation and maintenance procedures. Mechanical and chemical cleaning methods may be used, and previous conservation treatments and adhesives may be removed. Next, consolidation of fragments and flaking glaze may be completed. For sculptures comprised with multiple ceramic parts joined with mortar, the grout may also require conservation intervention. Gradations in plastics are not reversible.

\section{Physical State of Outdoor Sculptures in Southwest Nigeria}

When outdoor sculpture fulfills its primary role of enhancing the beauty of the environment where it is situated, it can be described as "a thing of joy and a thing of pride" The number of sculptures that adorn various public spots in some towns and cities of Southwestern Nigeria are surprisingly large and one would be proud of them; however, the sordid state in which some of them are does not allow one to appreciate the essence of their being in place. Only those are located in some restricted-access public places (such as palace premises and government reserved areas are in an admirable state, while others located mostly in unrestricted-access public places (road junctions, roundabouts and parks) yearn for care.

Some of the peculiar problems of most outdoor sculptures in Southwest Nigeria have to do with environmental degradation, wrong location, and sordid workmanship, and in some cases, human abuses coupled with unprecedented neglects on the part of the stakeholders. Outdoor sculptures, once put in place, are left at the mercy of weather and uninformed public, and it'sno longer owned by anybody going by the level of negligence. The sculptures endure daily threats from different sources. These may include unfriendly or hostile environment with high humidity and the warmth of the sun combined to cyclically hydrate and dehydrate the concrete which most of the outdoor sculptures are made of. Bacteria, algae, and other organisms that thrive in damp environments have also made homes on many pieces of the outdoor sculptures, and their byproducts are typically corrosive in nature. As erosion occurs, the outer surfaces of sculptures are chemically altered especially the fiberglass type, eventually detaching and falling off completely when not remedied. Examples include the Oduduwa statue in Ile - Ife as seen in Plate 1, the extinct Bata Metal Drummer (Plate 2), Sango statue in Marina Street, Lagos, Lisabi in Abeokuta, military statues of Adekunle Fajuyi and Ademulegun in Ado-Ekiti and Ondo towns respectively to mention a few (Plates 3-15).

\section{Some outdoor sculpture in Southwestern Nigeria}

The emergence of public outdoor sculpture in Nigeria has in no doubt provided a platform for artistic engagement and challenge among the Nigeria contemporary artists. The preponderant use of outdoor sculpture for public environment, in the Southwestern part of the Country has also afforded us, opportunity to appreciate and assess the capacities and capabilities of the outdoor sculpture artists; within

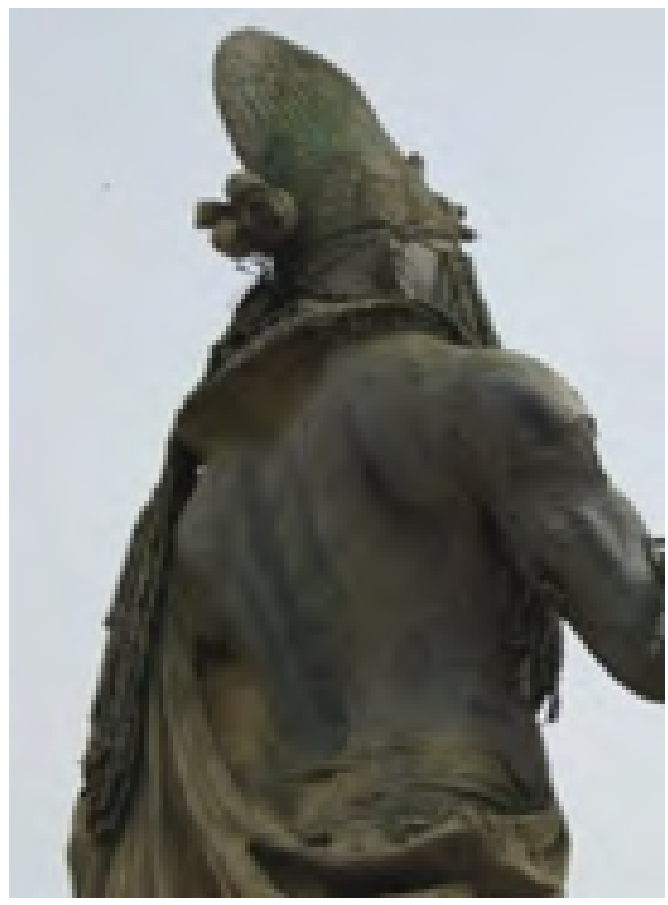

Plate 1: "Oduduwa Statue" (Fibreglass) Inset showing the effect of weather on the shoulder and drapery of the statue, before it was rescued prior the coronation of the new Oba- HRM Enitan Ogunwusi, Ojaja II, Ooni of Ife.

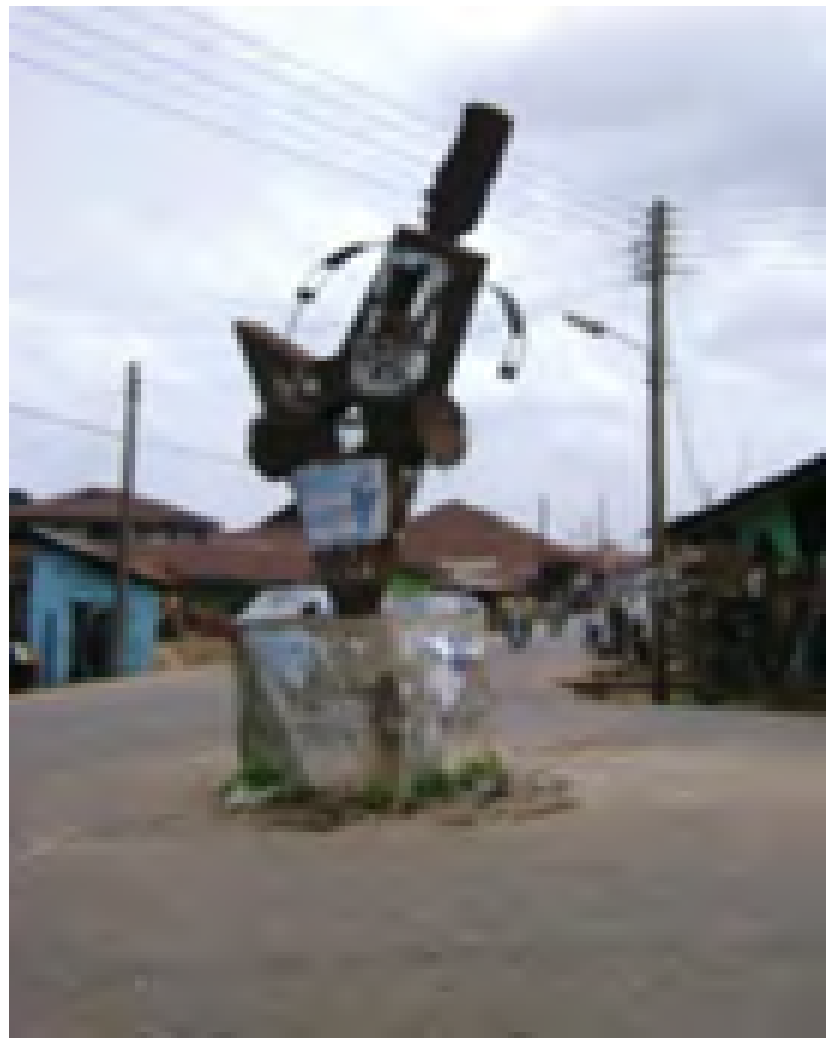

Plate 2: Bata Drummer (Metal) It Experienced corrosion from the surface and welded joints until it collapsed and it's no more. 
Citation: Oluwasegun A, Yemi I, Emanuel B, Aremu PSO (2016) Analysis and Significance of Weather and Climatic Trend on Outdoor Sculptures in Southwest, Nigeria. J Environ Anal Toxicol 6: 400. doi: 10.4172/2161-0525.1000400

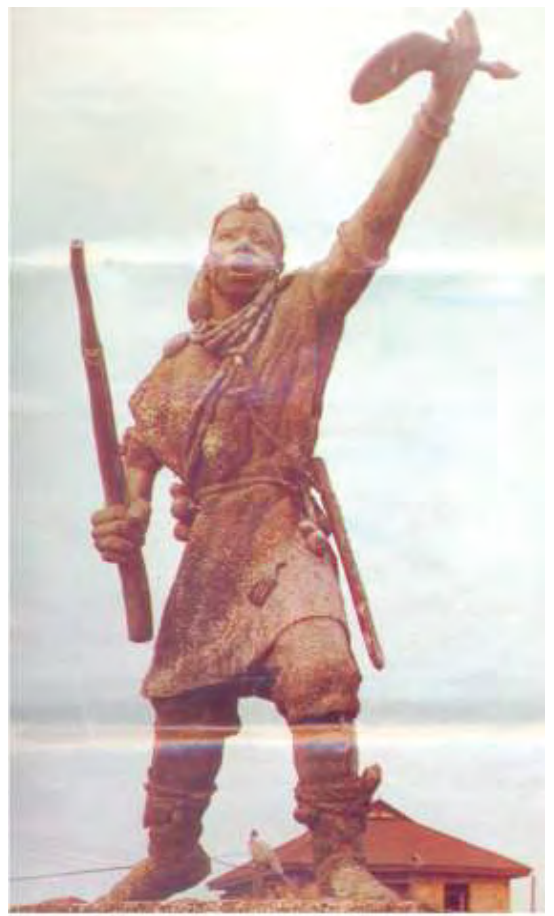

Plate 3: By Tiri Oladimeji, Iba Oluyole (Cement), Tiri Oladimeji, Iba Oderinlo, Cement, Height: 300 m, 1987, Beere, Ibadan. Height: 270 cm, 1991, Mapo, Ibadan. Photograph by Trans Assurance Plc. 1996 Photograph by Akintonde Moses, 2007.

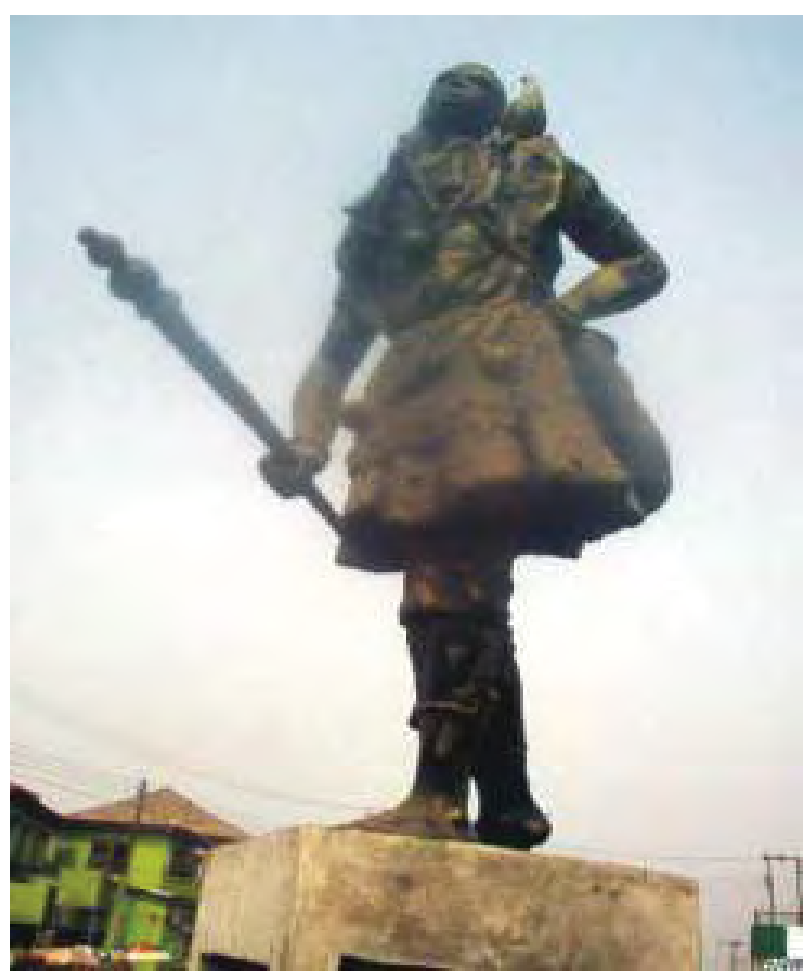

Plate 4: By Tiri Oladimeji, Iba Oluyole (Cement), Tiri Oladimeji, Iba Oderinlo, Cement, Height: 300 m, 1987, Beere, Ibadan. Height: 270 cm, 1991, Mapo, Ibadan. Photograph by Trans Assurance Plc. 1996 Photograph by Akintonde Moses, 2007.

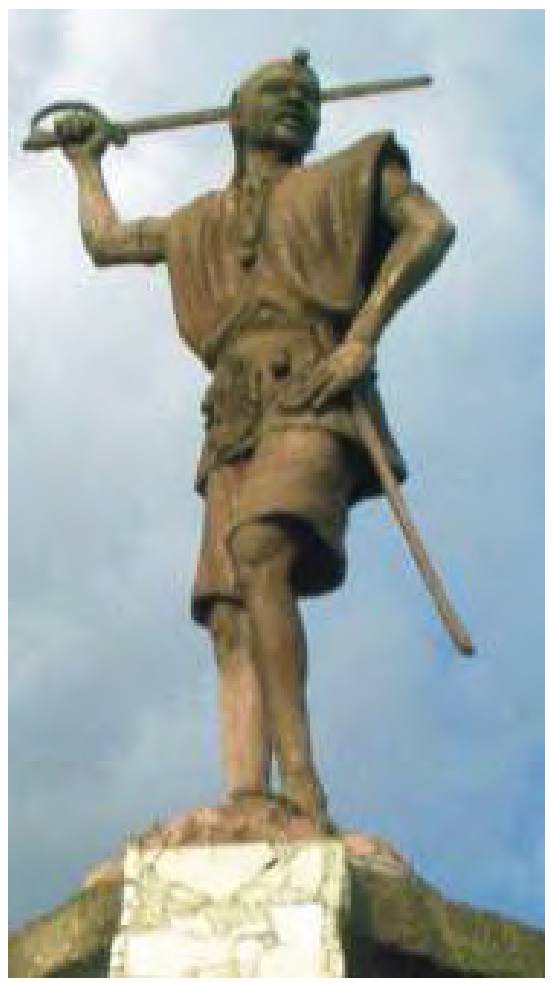

Plate 5: By Saburi Adebesin, Lisabi Agbongbo Akala, Fibre glass, height: 180 $\mathrm{cm}, 2004$, Itoku, Abeokuta. Photograph by Moses Akintonde, 2007.

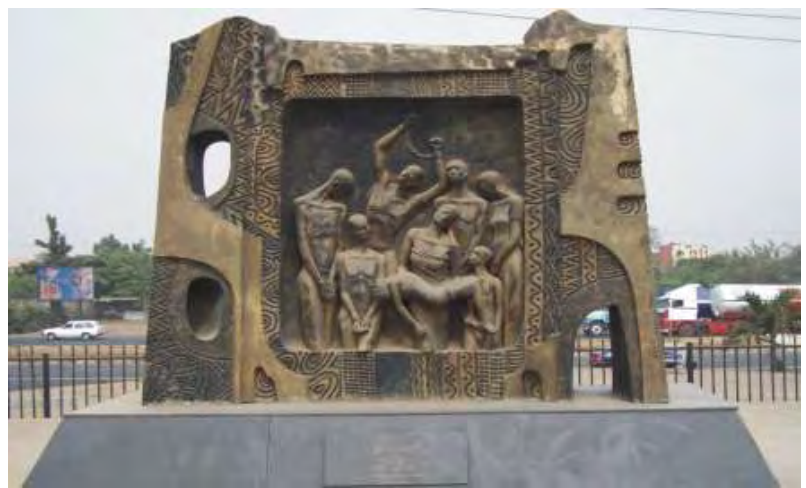

Plate 6: By Kenny Adamson, Monument to Kudirat Abiola, fibre glass, (390 × $360 \times 90) \mathrm{cm} \mathrm{2004}$, Seven-Up, Ikeja, Lagos. Photograph by Sola Ogunfuwa, 2007.

the socio-context of Yoruba culture [9].

Ref. [10] observes that when the centenary of the Benin massacre of 1897 was marked in Benin in 1997, not less than six sculptures were produced to commemorate the occasion; this seems a spectacular phenomenon, but the development noticed was mainly in terms of various materials used and the number produced, at the expense of quality; most of the sculptures produced for the centenary were not of estimable standard. This assertion is quite relevant as it is similar to the state of some of the sculptures in southwest Nigeria.

The climate of Nigeria in particular Southwest of Nigeria is 
Citation: Oluwasegun A, Yemi I, Emanuel B, Aremu PSO (2016) Analysis and Significance of Weather and Climatic Trend on Outdoor Sculptures in Southwest, Nigeria. J Environ Anal Toxicol 6: 400. doi: 10.4172/2161-0525.1000400

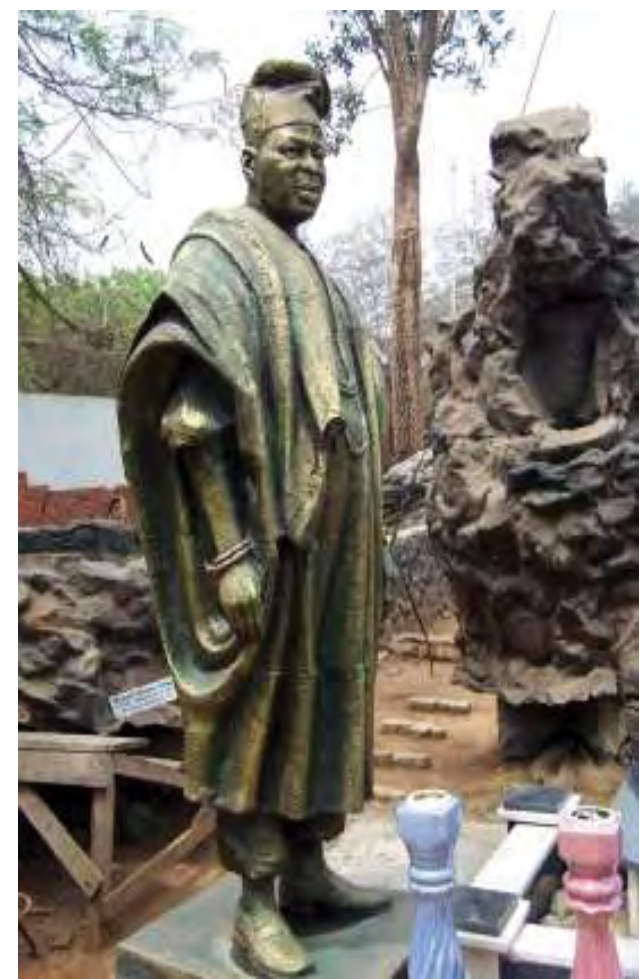

Plate 7: By a statue made by Akinlonu Photograph by Akintonde Moses, 2007

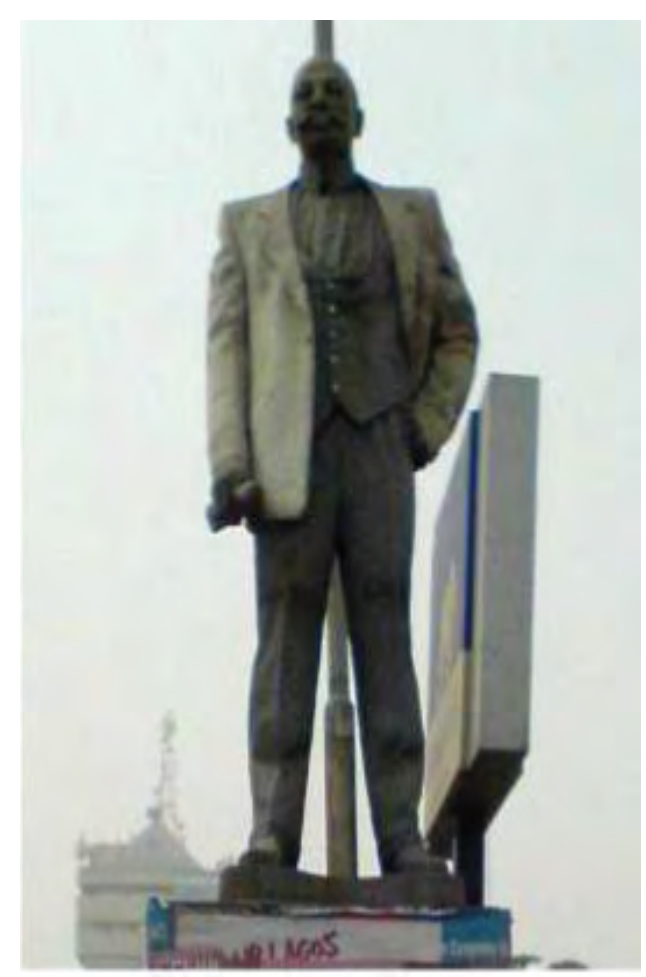

Plate 8: Tolu Filani. Herbert Marcula and Tai Solarin, Fibre glass, height: 210 cm, 1986 Fibre glass, height: $195 \mathrm{~cm}, 2002$. Herbert Macaulay Street, Sabo, Lagos. Yaba, Lagos. Photograph by Moses Akintonde, 2007 Photograph by Sola Ogunfuwa, 2007.

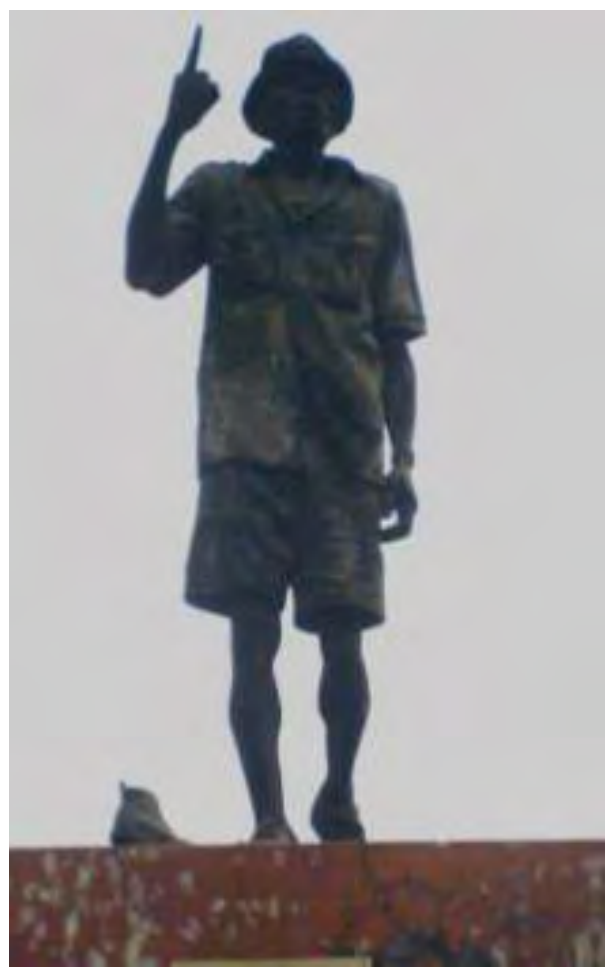

Plate 9: Tolu Filani. Herbert Marcula and Tai Solarin, Fibre glass, height: 210 cm, 1986 Fibre glass, height: $195 \mathrm{~cm}, 2002$. Herbert Macaulay Street, Sabo, Lagos. Yaba, Lagos. Photograph by Moses Akintonde, 2007 Photograph by Sola Ogunfuwa, 2007.

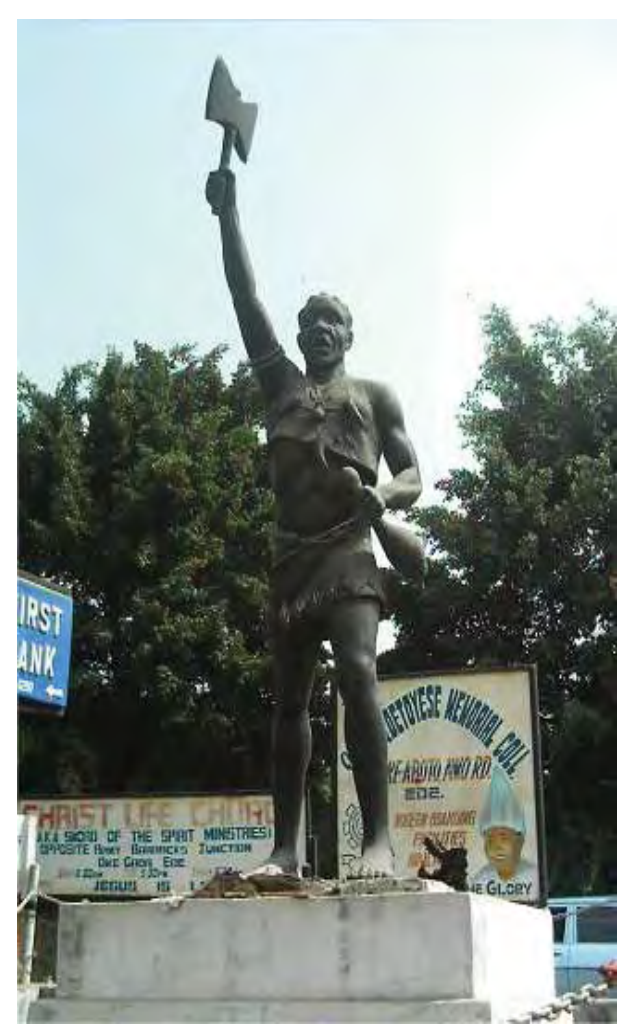

Plate 10: By Akah Bunak, Sango-Timi, cement, Height: $300 \mathrm{~cm}$, Okegada, Ede. Photograph by Akintonde Moses, 2004. 
Citation: Oluwasegun A, Yemi I, Emanuel B, Aremu PSO (2016) Analysis and Significance of Weather and Climatic Trend on Outdoor Sculptures in Southwest, Nigeria. J Environ Anal Toxicol 6: 400. doi: 10.4172/2161-0525.1000400

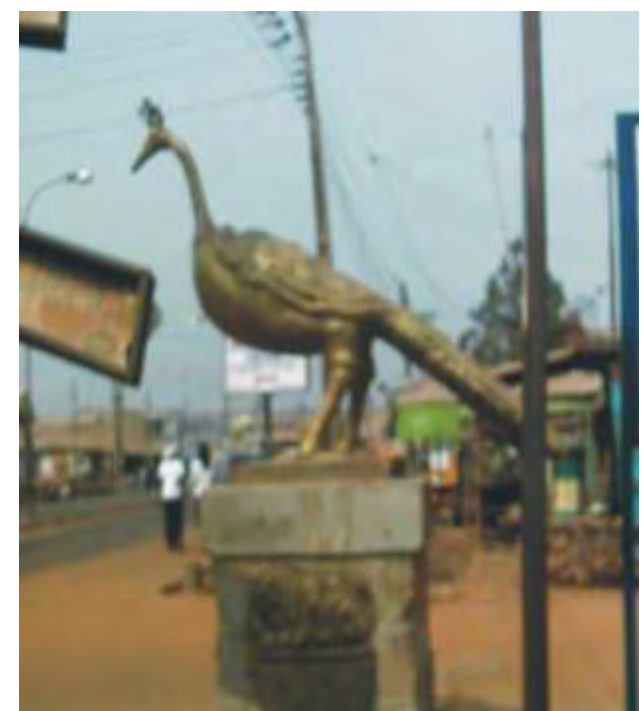

Plate 11: Rasheed Esso, Okin (Ostrich), cement, height: $75 \mathrm{~cm}$, Offa. Photograph by Akintonde Moses, 2004.

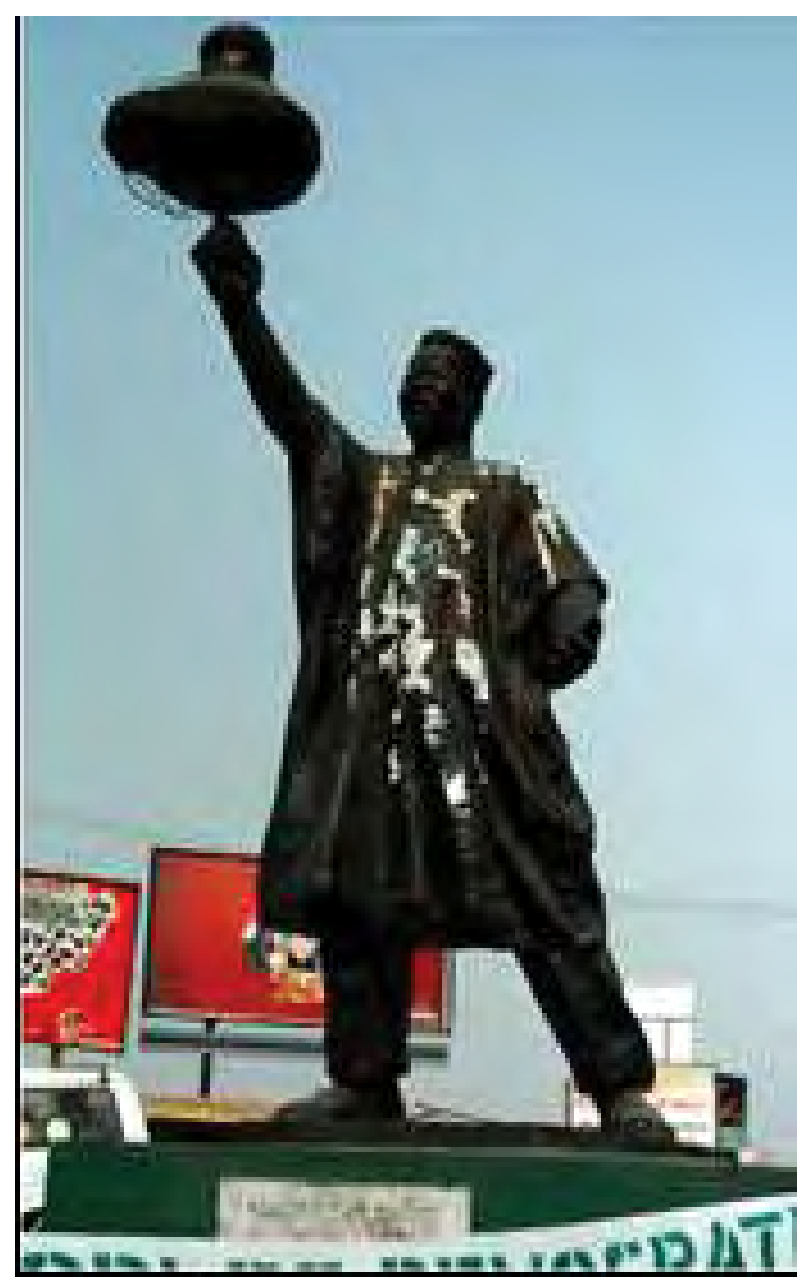

Plate 12: ByAkintonde Moses, Baba Onisekere, Cement, height: $285 \mathrm{~cm}$, 1991, Ayetoro Junction, Osogbo. Photograph: Akintonde Moses, 2007.

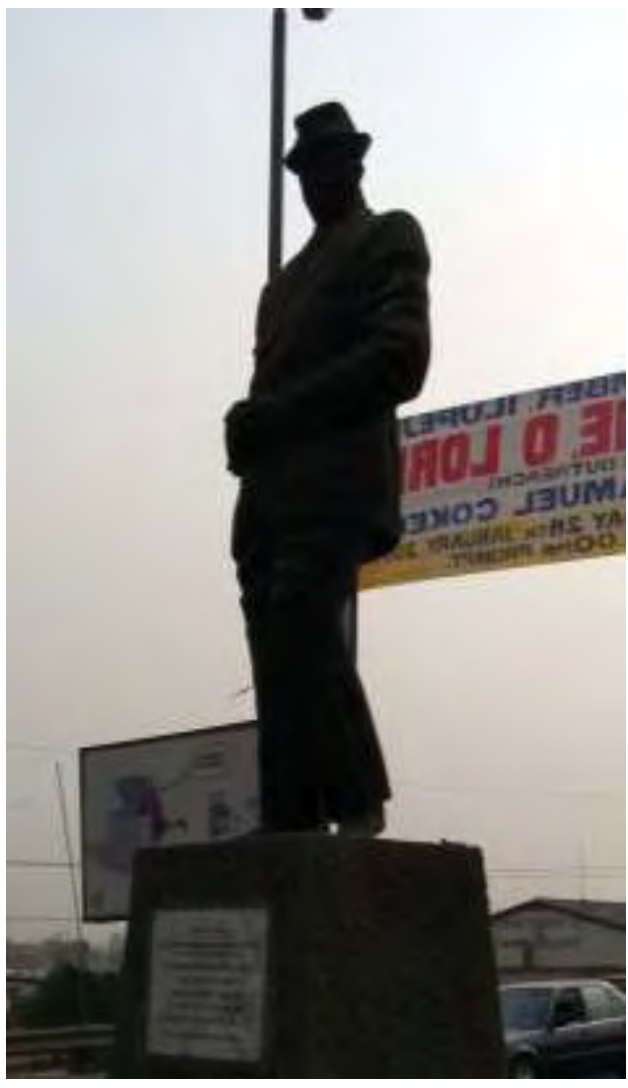

Plate 13: By Nwadugu E and Bane FO, Mobolaji Bamk Anthony, Cement, height: $210 \mathrm{~cm}$, 1989, Lagos State Teaching Hospital Road, Lagos. Photograph: Akintonde Moses, 2007.

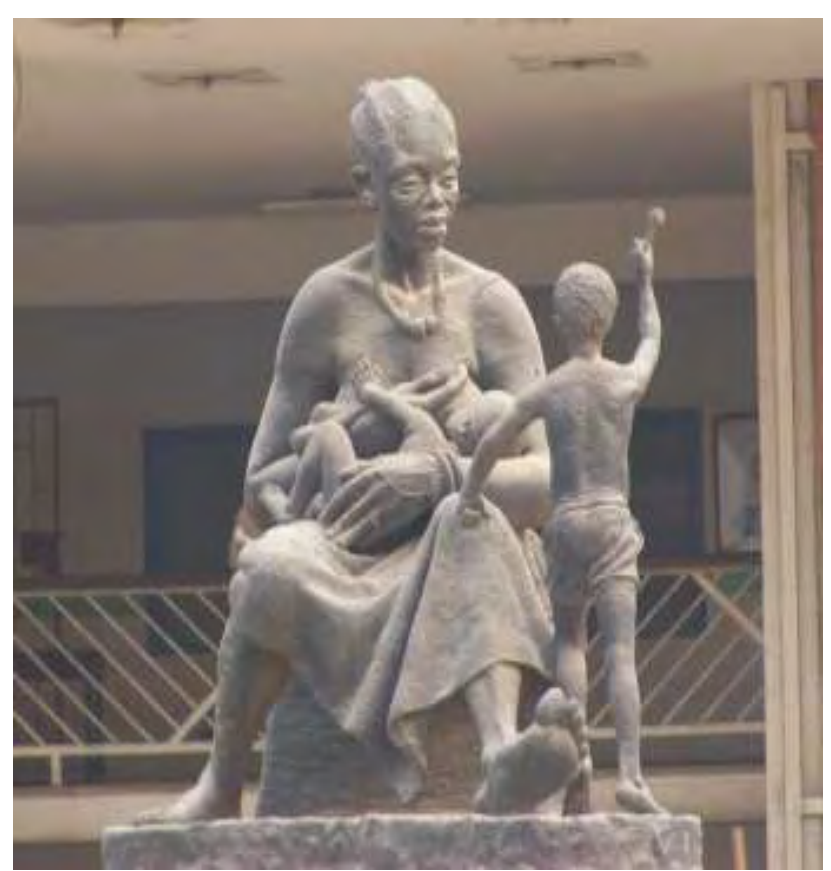

Plate 14: By Tony Emordi, Mother and Child, Fibre glass, height: $150 \mathrm{~cm}$, 1991, Ayike House, Lagos State Teaching Hospital, Lagos. Photograph: Ogunfuwa Sola, 2007. 
Citation: Oluwasegun A, Yemi I, Emanuel B, Aremu PSO (2016) Analysis and Significance of Weather and Climatic Trend on Outdoor Sculptures in Southwest, Nigeria. J Environ Anal Toxicol 6: 400. doi: 10.4172/2161-0525.1000400

Page 7 of 15

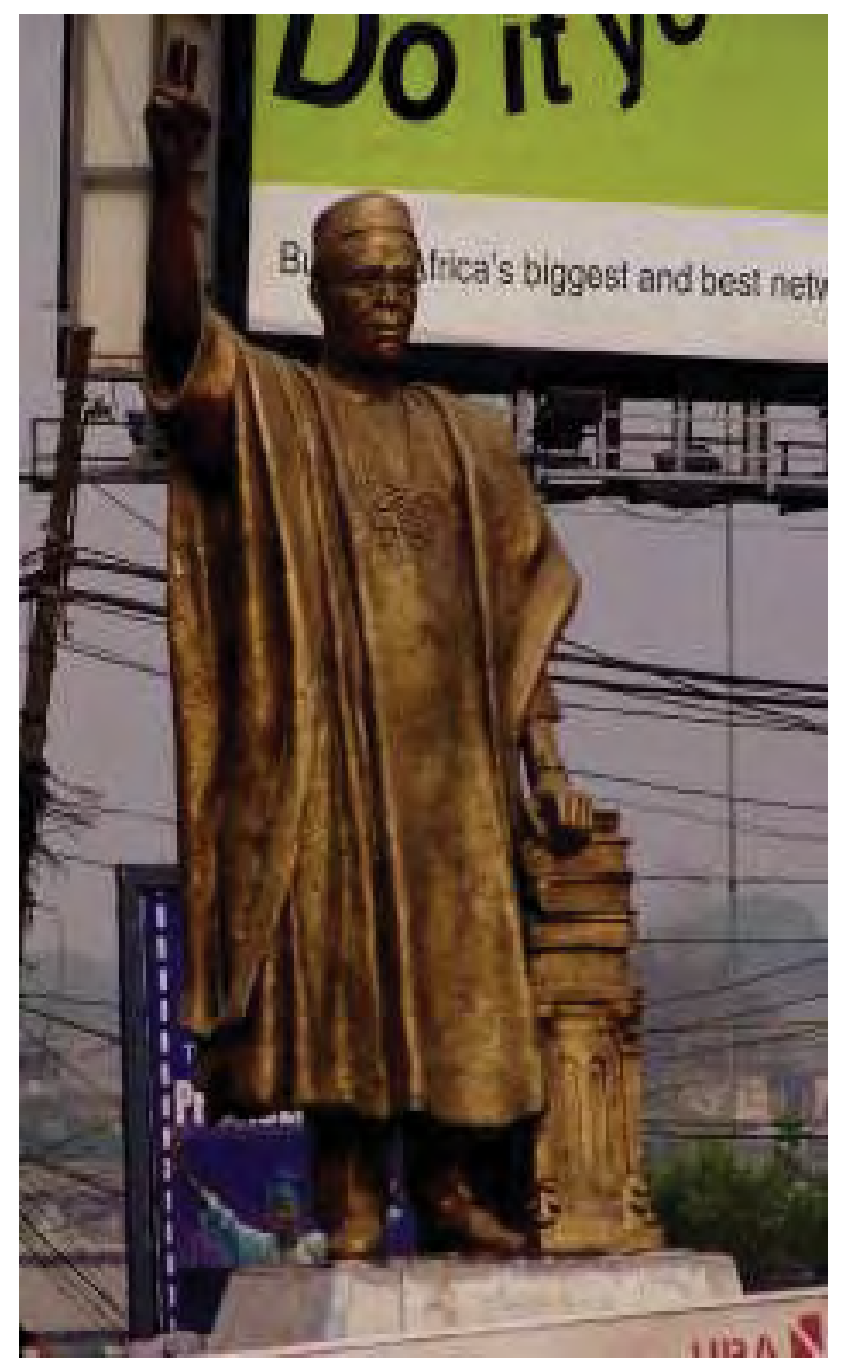

Plate 15: By Adeola Balogun, Obafemi Awolowo, Fibre glass, height: $240 \mathrm{~cm}$, 2002, Allen Junction, Ikeja, Lagos. Photograph by Akintonde Moses, 2007.

dominated by the influence of three major meteorological features, namely: the tropical maritime (mT) air mass; the tropical continental (cT) air mass, and the equatorial easterlies. The first two air masses ( $\mathrm{mT}$ and $\mathrm{cT}$ ) meet along a slanting surface called the Inter-tropical Discontinuity (ITD). The equatorial easterlies are rather erratic and relatively cool air masses from the east in the upper troposphere along the ITD. The position of the ITD is a function of the season with considerable short-period fluctuations. Generally, however, it is situated well to the north in July and August, thereby allowing the area to be totally under the influence of $\mathrm{mT}$ air mass. It is located south of the zone from October to June [11] (Figure 1).

South West Nigeria is predominantly the Yoruba race, they are a large ethno-linguistic group or ethnic nation in Africa, and the majority of them speak the Yoruba language. The Yoruba constitute approximately 35 percent of Nigeria's total population, and around 40 million individuals throughout the region of West Africa. Economically, Yoruba people primarily engage in agriculture, with about $15 \%$ of the people employed as merchants or artists and craftsmen. The Yoruba are the main ethnic group in the States of Ekiti,
Lagos, Ogun, Ondo, Osun, and Oyo, which are subdivisions of Nigeria; they also constitute a sizable proportion of Kwara and Kogi States as well as Edo State. Outdoor sculptures are commonly found in these areas and are located in specific areas to capture the interest of passerby's. The above mentioned influences of the meteorological features greatly affect the outdoor sculptures in the study area.

\section{Data Analysis}

Data for, relative humidity and air temperature that have great influence on these sculptural pieces have been analyzed with special reference to five synoptic meteorological stations in the South West of Nigeria (Lagos, Oyo, Ogun, Ekiti, Osun and Ondo states). The data were sourced from the archive of the Nigerian Meteorological Agency (NiMet) in Lagos, Nigeria. The data of each station and their spatial averages were plotted as graphs into which two types of trend lines were fitted, i.e., five-year moving average and a second order polynomial curve.

Data for the research comprising of daily maximum and minimum temperature (TMAX and TMIN from respectively), daily relative humidity and rainfall values of some weather stations in the south western part of Nigeria i.e., Ibadan, Ikeja, Abeokuta, Ado-Ekiti, Oshogbo and Ondo, spanning a time interval of 34 years (1981-2014) were obtained from the Nigerian Meteorological Agency, NiMet. Using software in Microsoft Excel, the daily average temperature values were obtained by taking the average of TMAX and TMIN i.e.,

$$
\text { Daily Average Temperature }=\frac{T M A X+T M I N}{2} \mathrm{~T}_{\mathrm{i}} \text {; }
$$

where $T_{i}$ is average daily temperature with $i=1,2,3 \ldots 365$ in days.

The resulting temperature values were then the averaged over the 365 days of the year to obtain annual average temperature values for each of the years. Similarly, the relative humidity data were averaged over the 365 days of the year to obtain the annual average relative humidity of each of the (34) years i.e.,

$$
T=1 / n \sum_{i=1}^{n} T i
$$

$\mathrm{T}$ is the annual average temperature and $\mathrm{n}=365$; and the annual average relative humidity is given by

$$
\frac{T M A X+T M I N}{2} \text {; where } \mathrm{n}=365 \text { days. }
$$

The annual rainfall was obtained by summing up the daily rainfall over the 365 days of the year i.e., Annual Rainfall, $R R=\sum_{i=1}^{n} R R i$;

where $\mathrm{RRi}$ is the daily rainfall, $\mathrm{nRR}=365$ days.

The annual average temperature, annual average relative humidity and annual rainfall data were then subjected to parametric $\mathrm{Z}$ test in order to ascertain the nature of the trend therein i.e., to ascertain if there has been a significant upward or downward trend in these climatic variables.

A trend is a significant change over time exhibited by a random variable, detectable by statistical parametric and non-parametric procedures. Using the $\mathrm{Z}$ test, it was tested whether the slope (which can also be considered as the trend in the data) of the regression to which the data points were fitted is statistically/significantly different from zero at the chosen level of significance. In this case the null hypothesis, $\mathrm{H}_{0}$, would state that the slope of the regression of the fitted data is zero, while the alternative hypothesis would state that the slope 
Citation: Oluwasegun A, Yemi I, Emanuel B, Aremu PSO (2016) Analysis and Significance of Weather and Climatic Trend on Outdoor Sculptures in Southwest, Nigeria. J Environ Anal Toxicol 6: 400. doi: 10.4172/2161-0525.1000400

Page 8 of 15

is significantly different from zero viz.,:

$$
\begin{aligned}
& \mathrm{H}_{0}: \text { the slope }=0 \\
& \mathrm{H}_{1}: \text { the slope } \neq 0
\end{aligned}
$$

Furthermore, the null hypothesis is based on the assumption that the mean of the slope of the regression lines computed from all the data samples (each of size $n=34$ ) that can be drawn from an identically distributed population of relative humidity or temperature data is zero i.e.,

$$
\mathrm{H}_{0}: \beta=0
$$

$\mathrm{H}_{1}: \beta \neq 0$; where $\beta$ represents the slope.

The $\mathrm{Z}$ value of the slope/trend is then calculated as: $Z=\frac{b-0}{\text {, }}$, where $S_{b}$ is the standard error associated with the slope of the regression. The regression is computed from the number of years and the relative humidity/temperature data. The computed value is then compared with the critical value of $Z$ which, at the $1 \%$ level of significance, is given by $Z= \pm 2.56$. Where the computed $Z$ value of the slope was found to be outside the range of the range of the critical values, the trend/slope is considered significant at the $1 \%$. Furthermore, if the calculated $\mathrm{Z}$ value of the trend/slope were to be positive, the data set would be said to have significant upward trend; if otherwise negative it would be said to have a significant downward trend.

However, where the calculated $\mathrm{Z}$ value falls within the range, the trend in the data is considered not significant at the \% level of significance. The test for significance of trend in the both the relative humidity and temperature data was conducted at the $1 \%$ level of significance.

\section{Presentation of the Results}

The results of the test for the significance of trend of the climatic variables at the $1 \%$ level of significance, over the weather stations, Ibadan, Ikeja, Abeokuta, Ado-Ekiti, Oshogbo and Ondo in Nigeria, are presented in this section. A table that shows a summary of the results of the significance of the trend at the $1 \%$ level of significance is also presented (Table 1). Over Ikeja the calculated $\mathrm{Z}$ value of the average annual temperature is 5.50 , which implies that there has been a significant upward trend in temperature values, over the years from 1981-2014, at the 1\% level of significance. Specifically, there is $99 \%$ confidence that there has been an increase in temperature over Ikeja (Figures $2 \mathrm{a}$ and $2 \mathrm{~b}$ ). The relative humidity has a calculated $\mathrm{Z}$ value of 2.033 , implying that there has been no significant change in relative humidity at the $1 \%$ level. Annual rainfall here showed an upward trend significant at the $1 \%$ level (calculated $\mathrm{Z}$ value of rainfall trend is 2.73 ).

Over Ibadan the calculated $\mathrm{Z}$ value of trend associated the average annual temperature is 2.65 , which implies that there has been a significant upward trend in temperature values, over the years from $1981-2014$, at the $1 \%$ level of significance. In other words, there is $99 \%$ confidence that there has been an increase in temperature over Ibadan (Figures 3-7). However, with a calculated $\mathrm{Z}$ value of 1.23 , there is no significant trend in relative humidity, RH, over the years i.e., 1981-2014 at the $1 \%$ level of significance. In other words, there is $99 \%$ confidence that relative humidity has not changed significantly during the period 1981-2014 over Ibadan. The calculated $Z$ value of rainfall trend here is 1.64 , indicating that there has been no significant change/trend in annual rainfall during the period under review.

Over Abeokuta, with a calculated $\mathrm{Z}$ value of 3.17 , the average annual temperature witnessed a significant upward trend at the $1 \%$ level of significance from 1981-2014. But the relative humidity, with a Z value of 0.65 , showed no significant trend at the $1 \%$ level of significance from 1981-2014. Similarly, annual rainfall here showed no significant trend/change at the $1 \%$ level given that the calculated $\mathrm{Z}$ value is 1.79 .

Over Ado-Ekiti, with a calculated $\mathrm{Z}$ value of -0.340 , the average annual temperature showed no significant trend at the $1 \%$ level of significance from 1981-2014, in other words there has been no significant change in temperature during the period under review. The relative humidity in this case, with a calculated $\mathrm{Z}$ value of -3.35 , however showed a significant downward trend from 1982-2014 i.e., there has been a significant decline of relative humidity, $\mathrm{RH}$, during the period under review. Annual rainfall here showed no significant trend at the $1 \%$ level given that the calculated $\mathrm{Z}$ value is -0.31 .

Over Oshogbo, the calculated $\mathrm{Z}$ value of the average annual temperature is 3.317 , which implies that there has been a significant upward trend in temperature values, over the years from 1981-2014, at the $1 \%$ level of significance. Relative humidity in this case, with a calculated $\mathrm{Z}$ value of -0.363 , shows no significant trend at the $1 \%$ level. Similarly, annual rainfall here with a calculated $Z$ value of -0.26 , showed no significant trend/change at the $1 \%$ level.

Over Ondo, the calculated $\mathrm{Z}$ value of the average annual temperature is 1.90 , which implies that there has been no significant trend in average temperature values from 1981-2014, at the $1 \%$ level of significance; similarly, relative humidity with a calculated $\mathrm{Z}$ value of -0.544 shows no significant trend during the period under review (1981-2014). With a calculated $\mathrm{Z}$ value of 1.05 , the annual rainfall showed no significant trend/change at the $1 \%$ level of significance.

\section{Maintenance policy of outdoor sculptures}

Outdoor sculptures face quite a number of challenges by their nature, in their environments. To ameliorate these challenges, finance is primary. One of the maintenance strategies will include finance, as opines by Ref. [12]. There is no gainsaying that the production of a good quality outdoor sculpture starts from the generosity of the owner of the work. If the job is affluently commissioned and reputable hands employed, there is the tendency to have art work that will be able to stand the test of time. For example, the issue of 'percentage for art' (which stipulates $1 \%$ of the total cost of a project be used for the

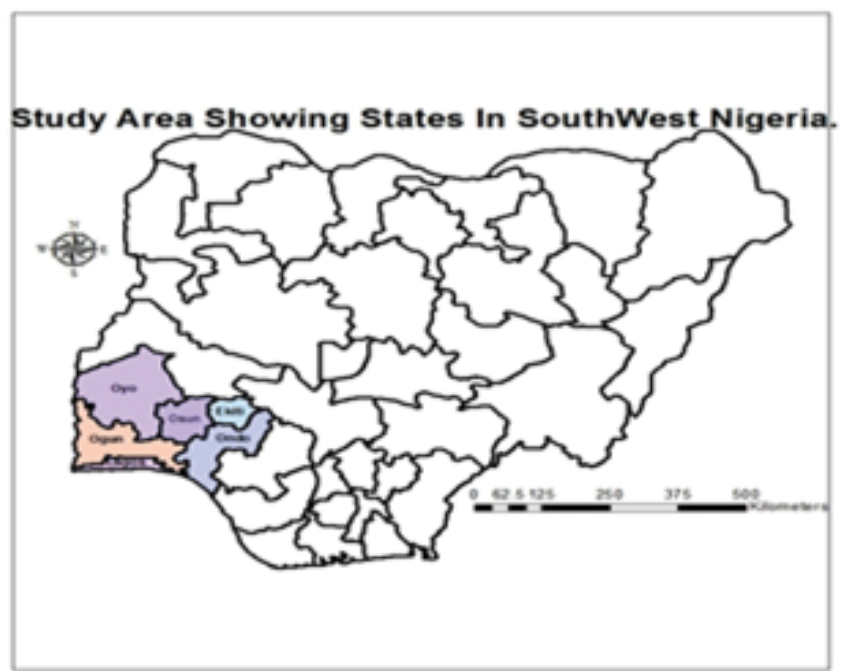

Figure 1: Map of Study Area. 
Citation: Oluwasegun A, Yemi I, Emanuel B, Aremu PSO (2016) Analysis and Significance of Weather and Climatic Trend on Outdoor Sculptures in Southwest, Nigeria. J Environ Anal Toxicol 6: 400. doi: 10.4172/2161-0525.1000400

Results of the Test for the Significance of Trend at the $1 \%$ Level of Significance

\begin{tabular}{|c|c|c|c|}
\hline \multicolumn{2}{|c|}{ Results of the Test for the Significance of Trend at the 1\% Level of Significance } \\
\hline Stations & For Temperature (1981-2014) & For Relative Humidity (1981-2014) \\
\hline Ikeja & Significant Upward Trend & No Significant Trend & Significant Upward Trend \\
\hline Ibadan & Significant Upward Trend & No Significant Trend & No Significant Trend \\
\hline Abeokuta & Significant Upward Trend & No Significant Trend & Significant Downward Trend \\
\hline Adoekiti & No Significant Trend & No Significant Trend & No Significant Trend \\
\hline Oshogbo & Significant Upward Trend & No Significant Trend & No Significant Trend \\
\hline Ondo & No Significant Trend & No Significant Trend & \\
\hline
\end{tabular}

Table 1: Summary of the Results of the parametric Z-test of Significance of trends in annual average temperature, $\mathrm{T}$ and annual average relative humidity, RH, and annual Rainfall, RR at the $1 \%$ level of significance, over the selected six stations in Western part of Nigeria.

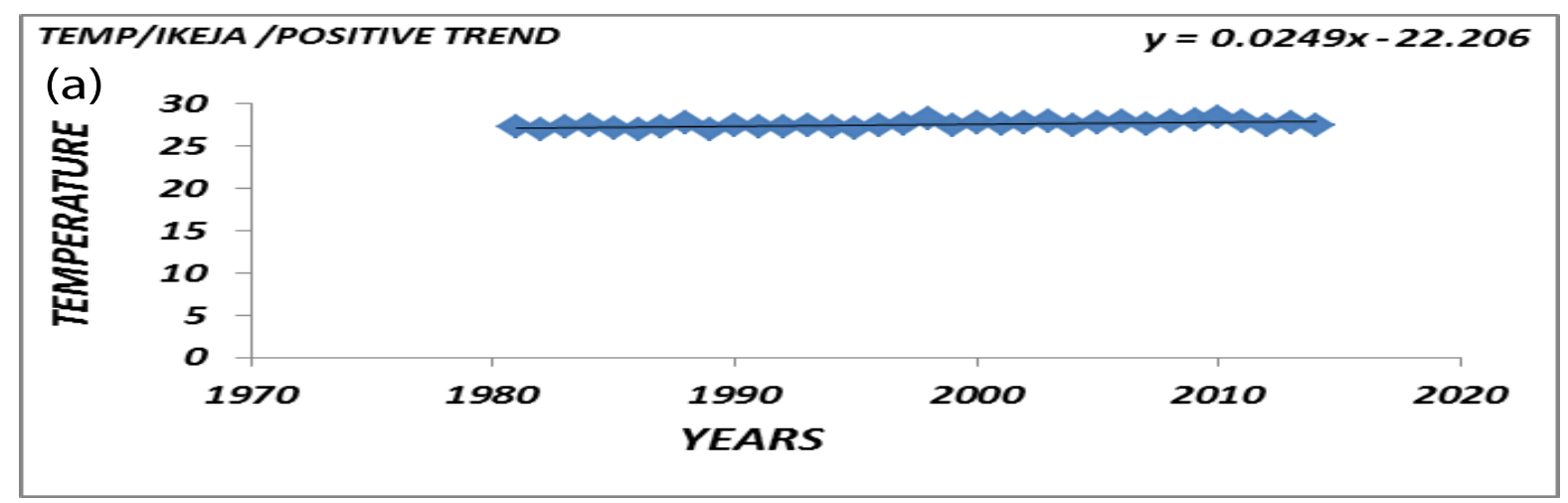

RH/IKJ /NO SIGNIFICANT TREND

(b)
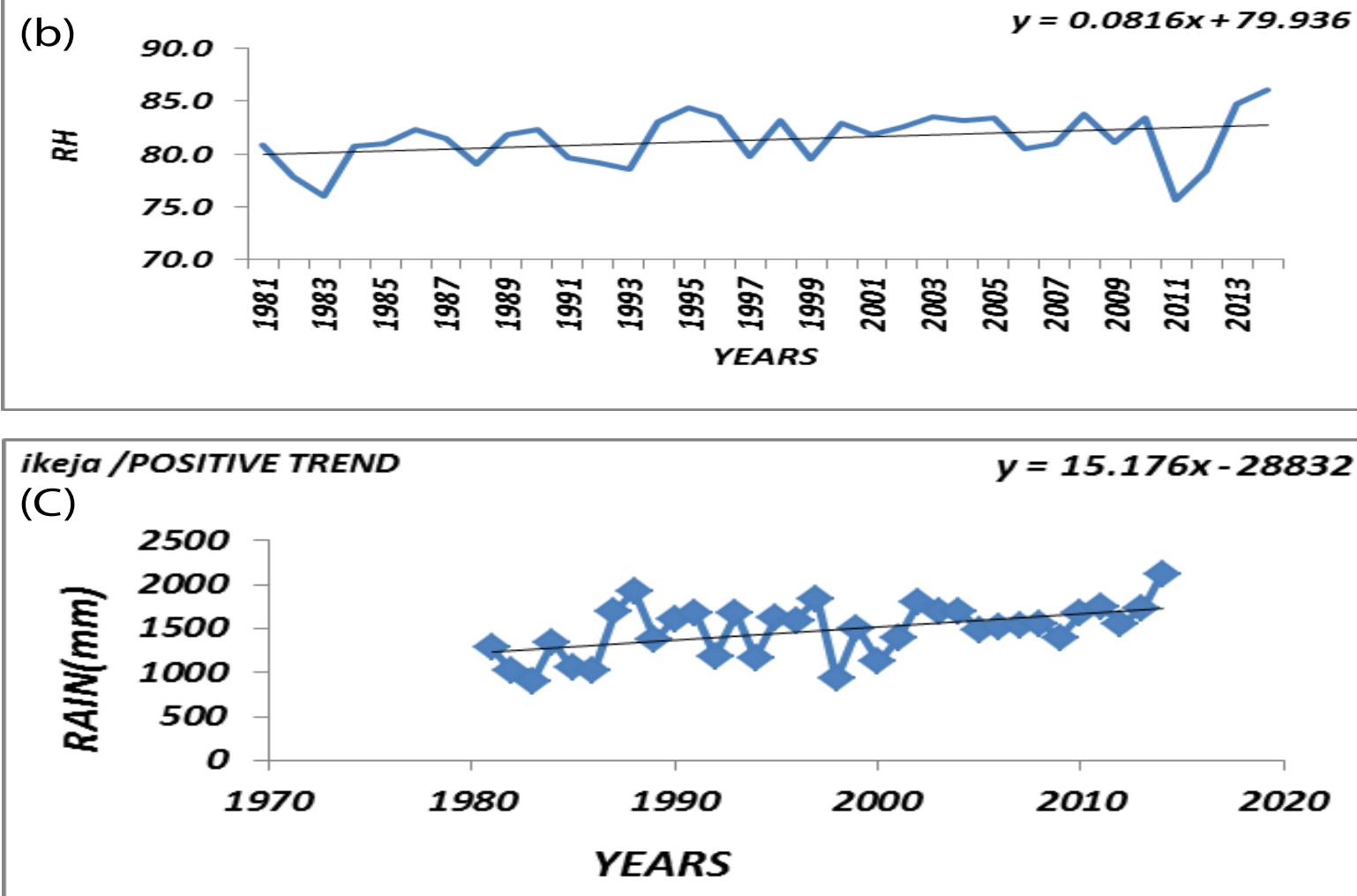

Figure 2: Annual average temperature (a), annual average RH (b), and annual Rainfall (c) over Ikeja (1981-2014). 
Citation: Oluwasegun A, Yemi I, Emanuel B, Aremu PSO (2016) Analysis and Significance of Weather and Climatic Trend on Outdoor Sculptures in Southwest, Nigeria. J Environ Anal Toxicol 6: 400. doi: 10.4172/2161-0525.1000400
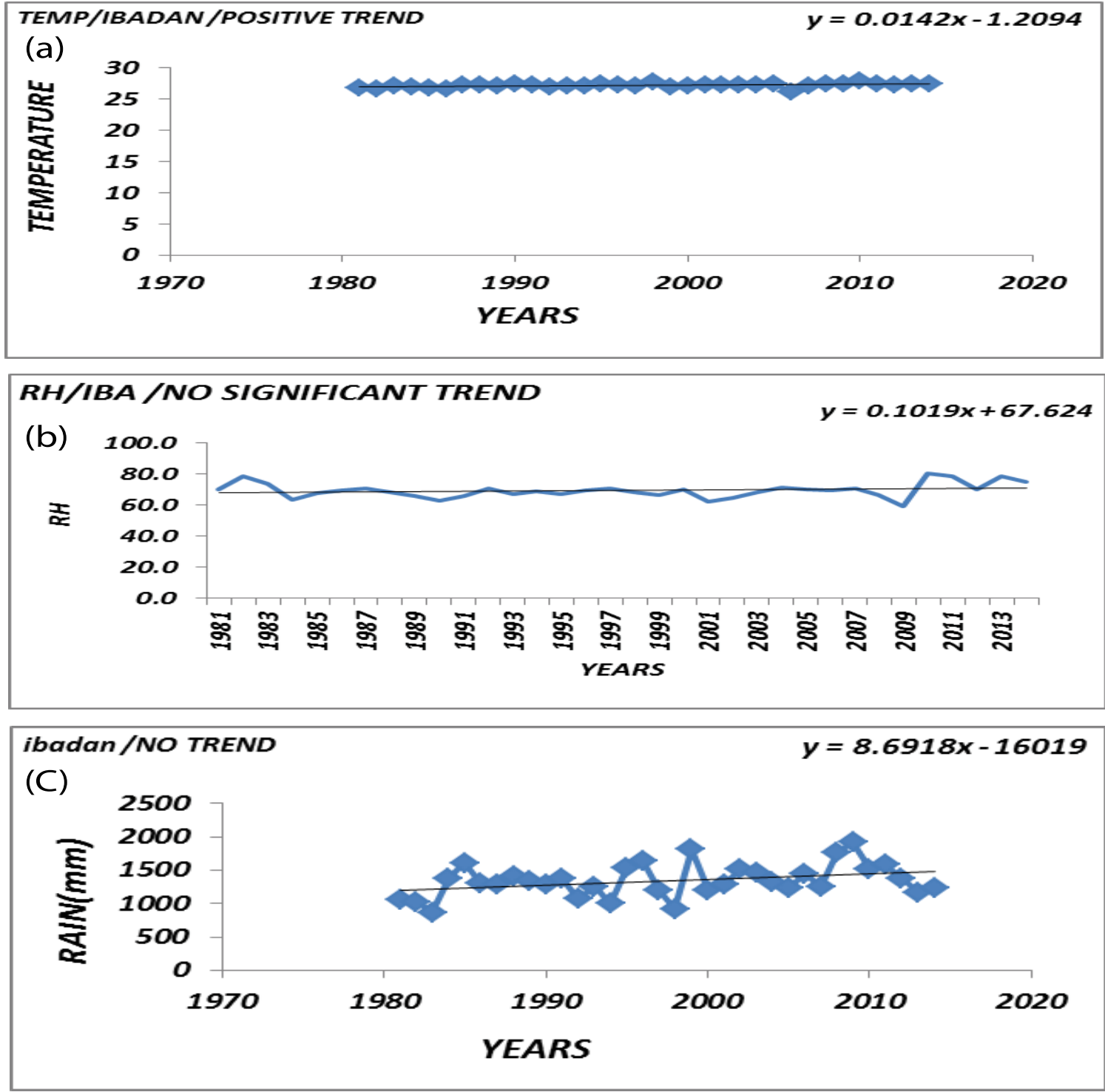

Figure 3: Same as in Figure 2 but over Ibadan.

provision of art by the U.S. government and later by other European countries) has yielded commendable results in the procurement and maintenance and preservation of outdoor sculptures. The issue of maintenance and preservation are very important and crucial as regards outdoor sculptures. The materials being used for these works are equally very crucial because inferior and substandard materials will affect the durability and standard nature as well as visual presentation. However, as good as this policy is, it is yet to receive the full blessing of policy makers in Nigeria.

Ref. [12] maintains that environmental conditions surrounding an outdoor sculpture can affect its condition, and suggests that encroaching vegetation should be cleared and weep-holes in the sculpture should always be kept clear, to allow water drainage. Furthermore, he advocates the discouragement of the public from touching or climbing on outdoor sculptures, in the sense that the applied surface coatings on them are easily scratched in the process, and will be worn away by excessive handling. This advocacy is pertinent in that it affirms the common knowledge that exposure to extremes of weather and continued public contact of outdoor sculpture, cause degradation, and damage occurs more quickly than for most other art collections that are not exposed to the open. These factors combine to make conservation of outdoor works both frequently necessary and very costly.

Ref. [5] asserts that maintaining outdoor sculptures can be a very challenging problem for conservators, curators, and collectors alike. Towing the path of Ref. [5,13], profess that materials change faster outdoor. When both the traditional (mud, clay, etc.) and modern materials (cement, bronze, etc.) are exposed to weather, pollution, and neglect, there is bound to be deterioration. Hence, nothing is certain in the conservation of outdoor works of art, but to strike a balance between the sculpture and the outdoor environment through regular maintenance. Ref. [14] in corroborating Pullen et al. asserts that outdoor sculptures are vulnerable to deterioration from pollution, lack of maintenance, vandalism and accidents, and that without proper care they eventually deteriorate, taking with them the stories 
Citation: Oluwasegun A, Yemi I, Emanuel B, Aremu PSO (2016) Analysis and Significance of Weather and Climatic Trend on Outdoor Sculptures in Southwest, Nigeria. J Environ Anal Toxicol 6: 400. doi: 10.4172/2161-0525.1000400
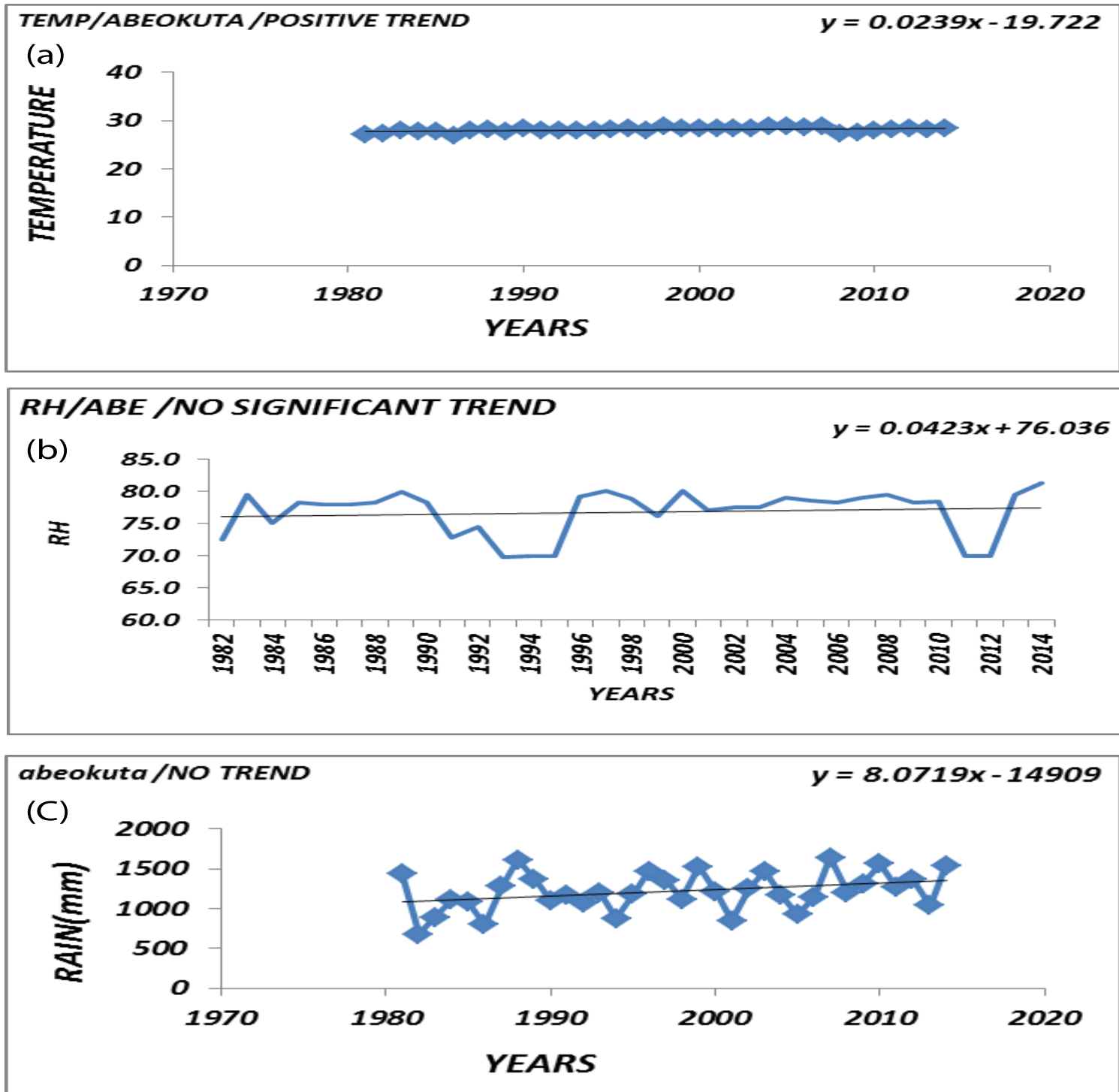

Figure 4: Same as in Figure 2 but over Abeokuta.

they tell. However, Mossholder is quick to add that while the threats cannot be eliminated, regular and appropriate care can mitigate them. In the light of this, it suffices to say that the maintenance of outdoor sculpture requires permanent, long-term commitment of museum staff and funds. Careful planning and good management of budgets are necessary.

There are various ways of solving a problem, it suffice to note that, education is pertinent to the preservation of outdoor sculptures, it helps people to understand what threatens outdoor sculptures. Ref. [15], addresses general issues of policy on commemoration and attitudes to the beautification of the metropolis with the use of outdoor art. In the process, he explores the instances of royal intervention, and the adaptation of bureaucratic structures within national and local governments to conserve and promote public art, along with relevant legislations.

Research work on outdoor art in Nigeria in general and southwest region in particular is silent on the issue of maintenance and preservation. Scholars that have researched into public sculptures, outdoor sculptures, urban arts or environmental sculptures have always used a blanket statement for the whole or part of Nigeria. But the fact remains that, the costs of public sculptures should be evaluated prior to acquisition by the parties involved, and again before installation, as this will determine how well the many challenges to be faced by outdoor sculptures in their environment will be tackled. There have been instances of some awarding bodies compromising quality jobs for meager cost by awarding jobs to non-qualified artists on the grounds of favoritism which invariably leads to sordid jobs that defile the necessary process of maintenance and preservation. To this end, it is pertinent to state that the enormous challenges faced by outdoor sculptures in their environment require a good understanding between the artist and the body contracting out the project, so as not to result in sub-standard projects due to non-compliance with standards by the artist (as a result of non-payment of appropriate fees). Substandard projects entail reduction in the quality of materials used. Materials that could not stand the test of time. Those which will yield to negative 
Citation: Oluwasegun A, Yemi I, Emanuel B, Aremu PSO (2016) Analysis and Significance of Weather and Climatic Trend on Outdoor Sculptures in Southwest, Nigeria. J Environ Anal Toxicol 6: 400. doi: 10.4172/2161-0525.1000400
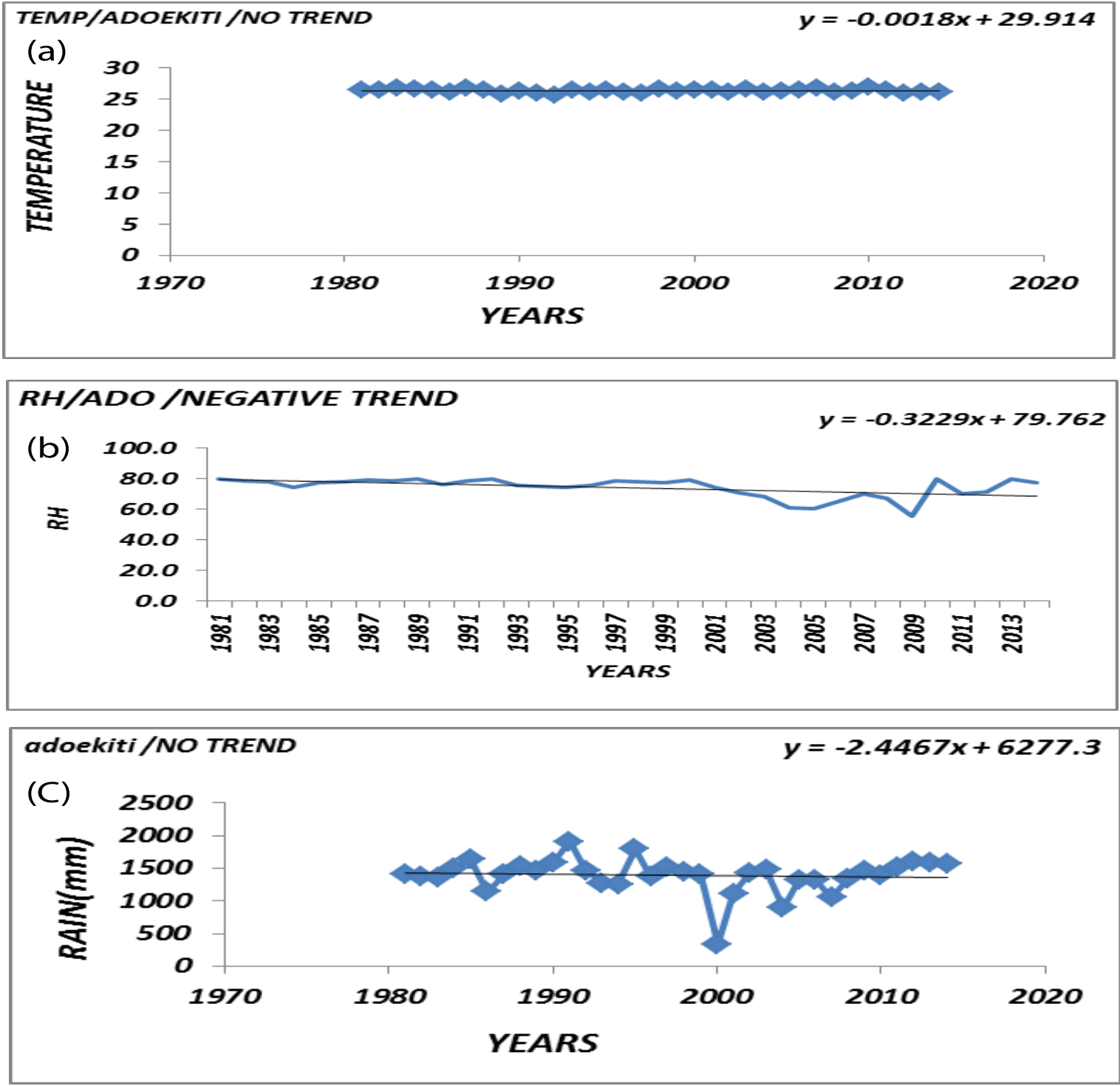

Figure 5: Same as in Figure 2, but over Adoekiti.

tendencies of nature. Such things as weathering, corrosion, weakness of materials, change in colour and other adversities that are caused by the effect of climatic condition could be taken care of with the accurate maintenance and quality materials being used. In like vein, the location of the study area which is south-west Nigeria is located in the tropical region of Africa. The location favors the harsh effect of rain, humidity, intense heat and drastic changes in the weather. All these comes with attendant adverse effect on outdoor sculptures.

\section{Importance of outdoor sculpture}

Outdoor sculptures consist of art objects in the round or relief form and are sited outside and exposed to the environment in the open space. They form an important cultural part of any community. The sculptures are sometimes created in remembrance of a particular event or for an important personality or political stalwart who has impacted the community in a grand way. Outdoor sculptures also are not unconnected with the replication of important landmark for the community in which they stand. Another silent but salient importance of outdoor sculptures is the beautification of the surroundings in which they are located.

\section{Conclusions}

The negative effects of weather on outdoor sculptures are real and finding qualified conservators to assist in maintenance program is the secret to success to maintaining equilibrium between art and homicide effect of weather. Maintenance of outdoor sculpture is a team effort, with participation from owners, artists, conservators and volunteers or trained technicians. This paper has found out that southwest Nigeria is blessed with quite a good number of outdoor sculptures that enliven her landscape and stand as testaments to her rich social, cultural and political history. It has equally been established that her outdoor sculptures are prone to weather threats as obtainable in other parts of the world. It is essential that those bodies charged with the responsibility of caring for the outdoor sculptures and other public arts respect their vulnerability and implement sound conservation and maintenance practice. The lofty ideas enumerated in the cultural Policy for Nigeria 
Citation: Oluwasegun A, Yemi I, Emanuel B, Aremu PSO (2016) Analysis and Significance of Weather and Climatic Trend on Outdoor Sculptures in Southwest, Nigeria. J Environ Anal Toxicol 6: 400. doi: 10.4172/2161-0525.1000400
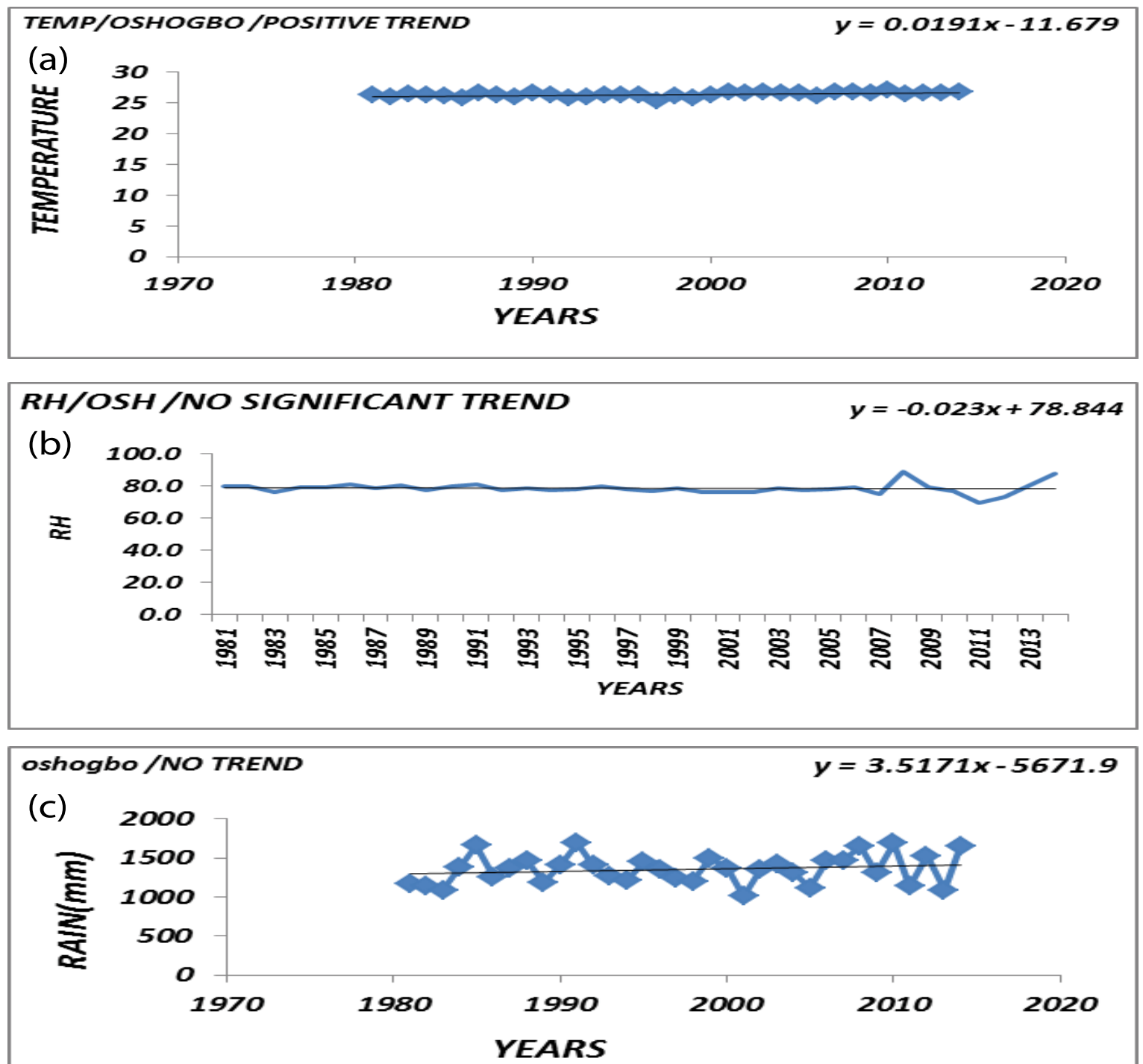

Figure 6: Same as in Figure 2, but over Oshogbo

ought to be fully implemented to further enhance the sustainability of outdoor sculptures in southwest Nigeria. What is worth doing, is worth doing well, it is pertinent to add that, only the competent hands (sculptors, architects, urban and regional planners, and conservators) should be involved in the execution and maintenance of outdoor sculptures. The present situation where we find some mediocre artists employed to carry out art projects on grounds of favoritism, and visual illiteracy should be avoided. The use of vulnerable materials that have in no small measure contributed to weakness of most observed outdoor sculptures should be dissuaded. It will be beneficial if materials that are more resistant to weather can be used for outdoor sculptures especially those in bronze. Bronze has always been expensive, but it is ideal for exterior use due to its comparative resistance to corrosion and its ability to take a fine, aesthetically pleasing finish. Government needs to be actively involved in encouraging the creation of outdoor sculptures through the application of "Percent for Art policy" that is - earmarking $1 \%$ of the construction cost for any public building for art. This is a standard for the artistic development and environmental serenity of most European countries where this policy has been in use for many decades. Though, the policy was equally introduced in Nigeria in the early 1960s but it has not been statutorily implemented. Though a bit of its implementation can be seen in operation in Government secretariat buildings at Abere, Osogbo where all the ministry buildings are complemented with a relevant sculptural piece serving as their logos. The policy needs to be improved upon and extended to other parts of the region for full implementation.

It is obvious that the part played by outdoor sculptures in any serene environment cannot be over emphasized. To this end, it would be necessary for all the stakeholders to put their resources together to generate outdoor sculptures that can compete well with those available in other parts of the world. It is commonly observed that a country is not judged alone by its political and economic development - its arts, literature, and music should also count. Only through a coherent government policy can cultural potentialities be fully developed.

The achievements and the virtues of the people represented in 
Citation: Oluwasegun A, Yemi I, Emanuel B, Aremu PSO (2016) Analysis and Significance of Weather and Climatic Trend on Outdoor Sculptures in Southwest, Nigeria. J Environ Anal Toxicol 6: 400. doi: 10.4172/2161-0525.1000400
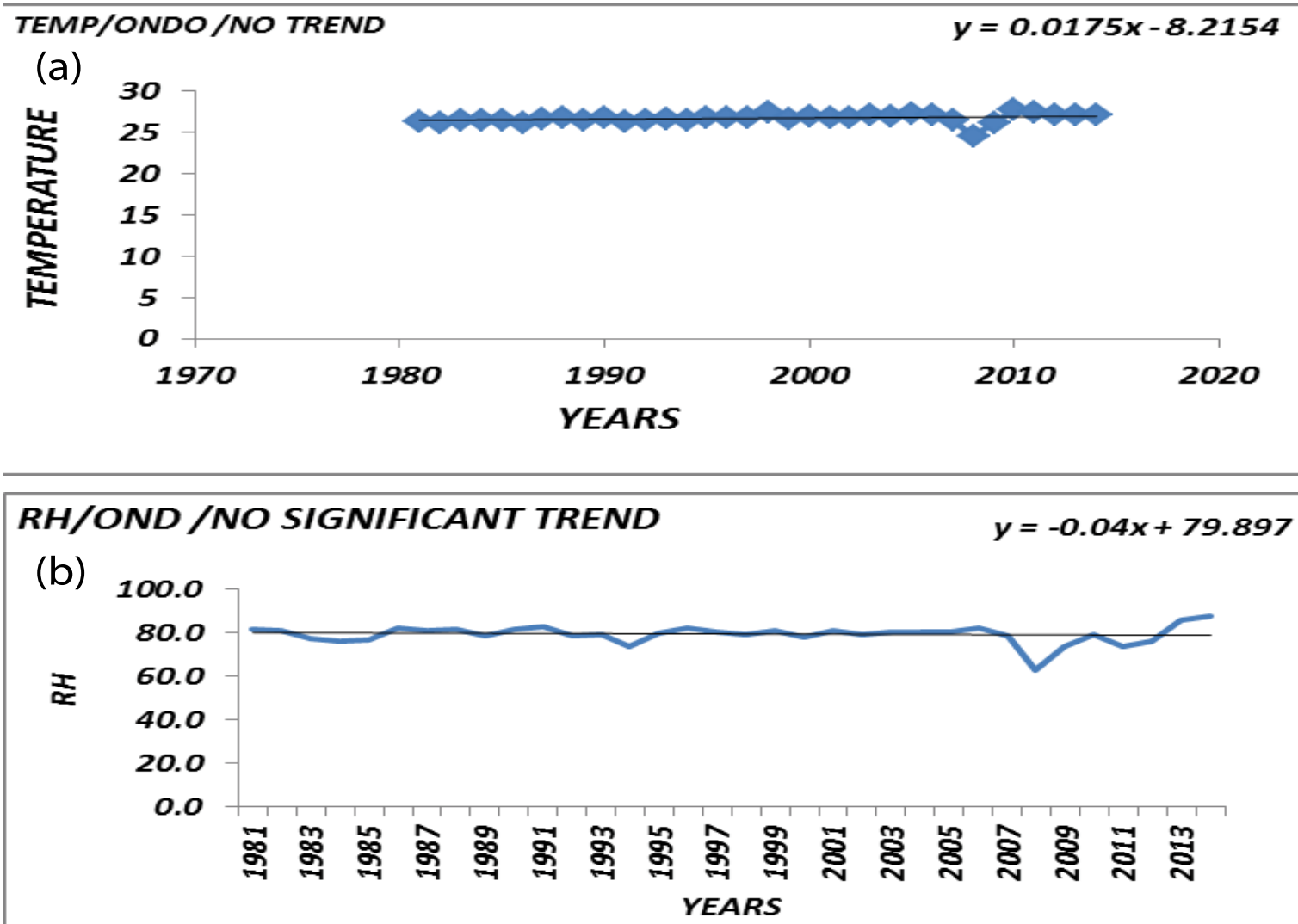

ONDO/NO TREND

$y=5.7361 x-9802.6$

(C)

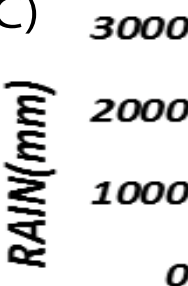

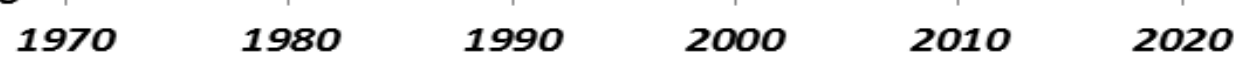

YEARS

Figure 7: Same as in Figure 2 but over Ondo.

these statues can help supply the emotional and psychological energy that could keep one going. In corroboration, Dianne [14] opines that there are a few limitations to statues - That is, statues can make one stop, look and think. That is to affirm that the essence of outdoor sculptures cannot be over emphasized because there is need for values, inspiration, and moral guidance they represent, even in the twentyfirst century. Therefore, outdoor or public sculpture should be a clever organization of facts and commentary that will enliven the spirit of the public positively. It should be an introduction to important ideas that could offer the observer rational guidelines to better appreciate and understand art in general.

\section{References}

1. Adedokun JA (1978) West African precipitation and dominant atmospheric mechanisms. Archiv fur Meteorologie, Geophysik und Broklimatologie, Serie A 27: 289-310.

2. DeChillo S (1991) Battling Nature in the Sculpture Garden. Outdoor sculpture in Ibadan metropolis: Form and content. MA Thesis, University of Ibadan, Nigeria.

3. Adamowski K, Bougadis J (2003) Detection of Trends in Annual Extreme Rainfall. Hydrological Processes 17: 3547-3560.

4. Odekunle T, Aremu OS (2008) Towards a wetter sudano sahelian ecological zone in twenty first century Nigeria. Royal Meteorological Journal 63: 3.

5. Hulme M, Doherty R, Ngara T, New M, Lister D (2001) African climate change: 1900-2100. Clim Res 17: 145-168. 
Citation: Oluwasegun A, Yemi I, Emanuel B, Aremu PSO (2016) Analysis and Significance of Weather and Climatic Trend on Outdoor Sculptures in Southwest, Nigeria. J Environ Anal Toxicol 6: 400. doi: 10.4172/2161-0525.1000400

Page 15 of 15

6. Boros D (2012) Public Art as Aural Installation: Surprising Musical Intervention as Civic Rejuvenation in Urban Life.

7. Willet $F(1966)$ The sculpture of Western Nigeria. Ibadan: Ministry of Information.

8. Segy L (1969) African sculpture speaks. New York, Hill and Wang.

9. Babalola O (1995) Contemporary Nigerian art: Message and implications for the world. USO Nigerian Journal of Art.

10. Mirza MQ, Warrick RA, Erickson NJ, Kenny GJ (1998) Trends and Persistence in Precipitation in the Ganges, Brahamaputra and Meghna basins in South Asia. Hydrological Sciences Journal 43: 845-858.
11. Adelowo GE (1999) Out-Door Sculpture in Ibadan Metropolis. Unpublished MA Thesis, African Studies, University of Ibadan, Nigeria.

12. Houghton JT, Meira Filho LG, Callander BA, Harris N, Kattenberg A, et al (1996) IPCC Climate change. In The IPCC Second Assessment Report Cambridge University Press: New York.

13. Pullen H (2007) Modern and Contemporary Sculpture Conservation: Challenges and Advances.

14. Mossholder D (2007) Save Outdoor Sculpture: A Community-Based Conservation Programme. Conservation at the Getty Newsletter 22.2 Spring.

15. Ward-Jackson P (2012) Public Sculpture of Historic Westminster. The National Recording Project Series - Public Sculpture of Britain. ISBN 9781846314926. 